\title{
The productivity of raw seeds and cuttings (leaf) of Salvia officinalis L. medicinal plants
}

\author{
Safargul Ulugova ${ }^{1}$, Umid Ruzmetov ${ }^{1 *}$, Abdushukur Hamzayev ${ }^{1}$, and Askarboy Yunusov ${ }^{1}$ \\ ${ }^{1}$ Research Institute of Forestry, 111104 Tashkent, Uzbekistan
}

\begin{abstract}
This article highlights the different portions of minerals in fertilizer mixture used for the acceleration of cultivation of the medicinal plant of Sage in soil - climatic conditions of Syrdarya region. The obtained results showed that different portions of minerals in fertilizer mixture have a positive effect on increasing the yield of seedlings and cuttings of the plant. When feeding with different sharings of mineral fertilizers used in an experiment, applying Nitrogen-90, Phosphorus - 60 and Potassium - $40 \mathrm{~kg} / \mathrm{ha}$ norms has given good results to the rapid growth of plants. This article provides information on the technology of intensive cultivation of seedlings and cuttings of Salvia plant.
\end{abstract}

\section{Introduction}

Medicinal plants are considered as globally valuable sources of new drugs [1, 2]. Furthermore, up to $80 \%$ of people in developing countries are solely dependent on herbal drugs for their primary healthcare, and over $25 \%$ of prescribed medicines in developed countries are come from the different wild plant species [3]. With the constantly increasing demand for natural health products, and secondary metabolites of medicinal plants, the application of medicinal plants is growing fastly throughout the world [4]. Nevertheless, the production of various medicinal plants has been accompanied by multiple problems (insufficient equipment, insufficient organization, both human and technical, incoherence of science and practice, fragmentation of programs, limited number of cultivated species, unsuitable varieties, small and fluctuating yields, underdeveloped market, unsatisfactory quality etc.) [5, 6]. Nowadays, the situation is gradually changing to the better. Numerous problems have been overcome; the structure of medicinal plant production has been notably improved. New varieties and new species are being introduced and the results of scientific research are being applied more and more [7-10]. The number of commodity producers is increasing both in the individual and social sectors, and the cultivation of medicinal plants is becoming their only or main occupation.

The nature of Uzbekistan is distinguished by its uniqueness, fresh water, sun, air and soil. The flora is very diverse and there are more than 4560 species of wild plants of which 577 are medicinal, 103 are dyes and 560 are essential oils. 250 species of such medicinal plants are being used in scientific medicine. Researches are also being conducted in Uzbekistan on the cultivation of medicinal plants in different soil and climatic conditions and the study of their bio ecological properties $[11,12]$.

Today, 2,500 species of 20,000 land plants found in the territory of the Commonwealth of Independent States have been found to have medicinal properties, of which about 250 species are widely used in scientific medicine. Today, more than 50 species of them are grown as medicinal plants. Now there are more than 4,500 species of wild plants in the territory of the Republic of Uzbekistan. Of these, 600 species have been identified as medicinal properties, of which 50 species are used in scientific medicine [13]. The need for medicines made from medicinal plants is growing day by day. This, in turn, requires a comprehensive study of medicinal plants and their wider use [14].

When the winter is very cold in Uzbekistan, the non-wooded branches of the medicinal Salvia will be freezed. The plant is heat-loving, loves light, drought-resistant. A good yield can be obtained from an established plantation for 1315 years. Taking into account the biological characteristics, areas are selected for planting, free from weeds, fertile, irrigated, well water leaked, groundwater is deep, away from highways [15].

Medicinal Salvia plant is grown in Moldova, Krasnodar and Ukraine. It is a perennial semi-shrub, reaching 20-50 cm in height. Flowering period is June and July. The content of essential oils in the leaves is $0.5-2.5 \%$. Picking of leaves is carried out during the flowering period of the plant. Salvia plant is widely used in medicine. In particular, it can be used in stomatitis, tooth powder, ulcers, inflammation of the liver, gastritis, hemorrhoids and other diseases [16].

Growing Salvia plant in well-irrigated soils with moderate mechanical content gives good results. Salvia plant is heatloving, light-loving, drought-resistant, it can get high yields using cultivated lands for 4-5 years. It is recommended to irrigate up to 7-8 times in the first year during the season. It has been suggested that $100-110 \mathrm{~kg}$ of nitrogen, $70 \mathrm{~kg}$ of

*Corresponding author: umid ruzmetov@mail.ru 
phosphorus and $50 \mathrm{~kg}$ of potassium fertilizers per hectare during the vegetation season give good results for good plant growth and development [17].

\section{Materials and Methods}

The aim of this study was medicinal Salvia (Salvia officinalis L.). Commonly used methods were used in the studies Dospekhov [18]. The phenological observations were conducted by Beydeman method. The initial stages of the main phases of plant development were recorded [19] and carried out according to State Standards (UzStd).

During the study, the yield of medicinal Salvia seedlings and cuttings was studied. The research was conducted in 2020 in the Syrdarya State Forestry Area in Syrdarya Region.

Agroclimatic indicators show that the Syrdarya region is located in desert, semi-desert and gray soils of Central Asia in terms of zonal-climatic conditions. Summer in the Syrdarya region is hot and dry, winter is moderate, and there are large fluctuations in temperature between daily and annual temperatures. The average annual air temperature in the region is around $+11.70 \mathrm{~S}$. The highest temperature is in June-July, it is $+39.30 \mathrm{C}$, and the coldest is in December, January, February, around -3.7-2.30C.

The relative humidity is not large, in April-May the average is 70-64, the minimum humidity is around $47-38 \%$. Monthly precipitation $1 ; 2 ; 3 ; 4 ; 32.3 ; 73.7$ in 5 months; $10.9 ; 80.3 ; 52.9 \mathrm{~mm}$. This state of nature leads to salinization of the soil and an increase in the demand of crops for water.

\section{Results and Discussions}

\subsection{The effect of mineral fertilizers on medicinal Salvia seedlings}

In the second year of the study, when a single model of medicinal Salvia seedlings was applied according to the norms of mineral fertilizers for the plant, it was as follows:

in the fertilizer-free control variant, the number of branches was 9 , the number of leaves was 158 , the root length was $142 \mathrm{~cm}$, and the leaf surface was $11.4 \mathrm{~cm}^{2}$. In the second variant, these figures were 10 branches, 176 leaves, $164 \mathrm{~cm}$ in root length and $11.9 \mathrm{~cm}^{2}$ in leaf area. In the third variant, the number of branches was 10 , the number of leaves was 210 , the root length was $198 \mathrm{~cm}$ and the leaf surface was $13.8 \mathrm{~cm}^{2}$. In the fourth variant, these figures were 11 branches, 263 leaves, $212 \mathrm{~cm}$ in root length and $15.7 \mathrm{~cm}^{2}$ in leaf area.

Table 1. The effect of mineral fertilizers on medicinal Salvia

\begin{tabular}{|l|c|c|c|c|}
\hline \multirow{2}{*}{ Variants } & \multicolumn{4}{|c|}{ For a single model plant } \\
\cline { 2 - 5 } & $\begin{array}{c}\text { number of leaves, } \\
\text { pcs }\end{array}$ & $\begin{array}{c}\text { number of } \\
\text { branches, } \mathrm{pcs}\end{array}$ & root length, sm & Leaf surface, $\mathrm{sm}^{2}$ \\
\hline Control & 158 & 9 & 142 & 11.4 \\
\hline $\mathrm{N}_{30} \mathrm{P}_{60} \mathrm{~K}_{40}$ & 176 & 10 & 164 & 11.9 \\
\hline $\mathrm{N}_{60} \mathrm{P}_{60} \mathrm{~K}_{40}$ & 210 & 10 & 198 & 13.8 \\
\hline $\mathrm{N}_{90} \mathrm{P}_{60} \mathrm{~K}_{40}$ & 263 & 11 & 212 & 15.7 \\
\hline
\end{tabular}

\subsection{Productivity indicators of seedlings growth of Salvia plant}

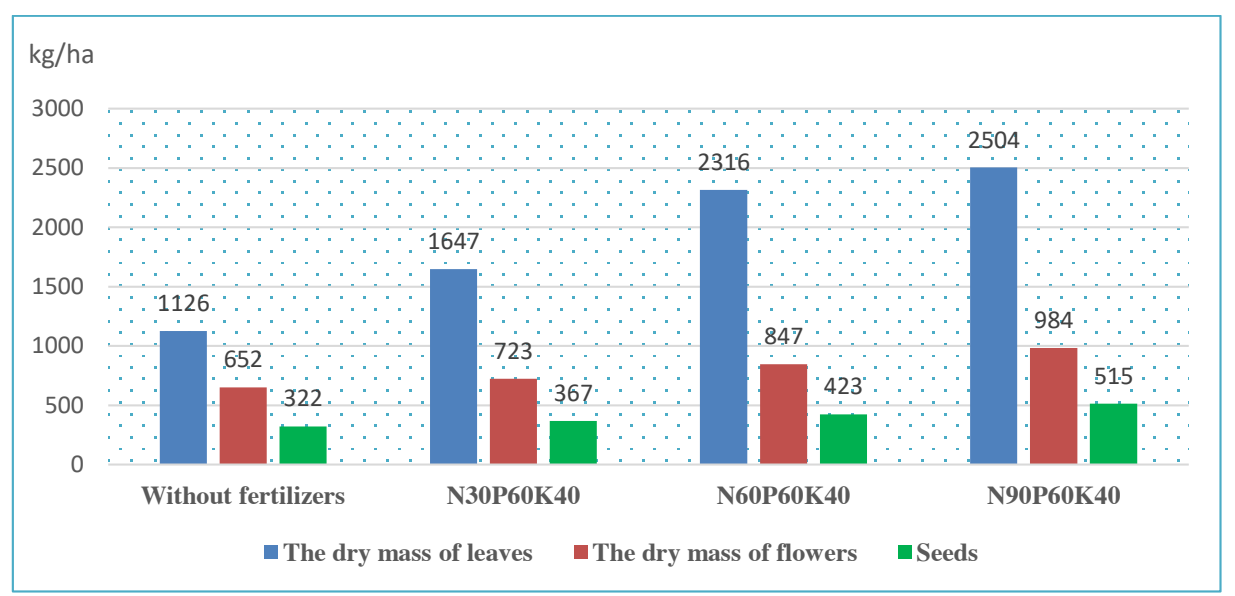

Fig. 1. Yield indicators of leaves, flowers, raw materials, and seeds of seedling development of salvia plant 
Diagonal method was used to determine the yield in medicinal Salvia plant seedlings in the experimental fields. The yield of medicinal Salviaa seedlings was collected based on 4 variants of 3 returns per $1 \mathrm{~m}^{2}$ and measured its wet weight. After determining the wet weight of the raw material, it was dried and re-measured and the yield was determined for an average of $1 \mathrm{~kg} / \mathrm{ha}$. The effect of applying different norms of mineral fertilizers on each options of Salvia seedlings was determined. In this case, the dry mass of raw material (leaves) per $1 \mathrm{~m}^{2}$ of medicinal Salvia seedlings in the control variant was $112.6 \mathrm{~g}, 1126 \mathrm{~kg}$ per hectare in the fourth option, 250.4 gram per $1 \mathrm{~m}^{2}, 2504 \mathrm{~kg} / \mathrm{ha}$. Compared to the control, the dry mass of the plant increased by 2.2 times, or $222 \%$.

The dry mass of flowers was $65.2 \mathrm{~g}(652 \mathrm{~kg} / \mathrm{ha})$ under control in $1 \mathrm{~m} 2$ area, $98.4 \mathrm{~g}$ per $1 \mathrm{~m}^{2}, 9840 \mathrm{~kg}$ per hectare in the variant applied with N90P60K40 norms of mineral fertilizers. It was observed that the dry mass of flowers was 1.5 times higher than the control, which was $150 \%$ higher.

The result was $32.2 \mathrm{~g}$ per $1 \mathrm{~m}^{2}$ of mature seeds of Salvia plant under control version. That is $3220 \mathrm{~kg}$ for per hectare. Similarly, in the second and third experiments the figures were $36.7 \mathrm{~g}, 3670 \mathrm{~kg}$ per hectare and $42.3 \mathrm{~g},(4230 \mathrm{~kg} / \mathrm{ha})$ respectively. But in the fourth experiment it was $51.5 \mathrm{~g}(5150 \mathrm{~kg} / \mathrm{ha})$. That was 1.5 times or 159 percent higher compared to control version (Fig. 1.). That was 1.5 times or 159 percent higher compared to control version (Figure 1.).

\subsection{The effect of mineral fertilizers on medicinal Salvia seedlings}

The development of medicinal Salvia cuttings was observed when applied according to the norms of mineral fertilizers for a single model plant as follows: in the fertilizer-free control variant, the number of branches was 10 , the number of leaves was 184 , the root length was $154 \mathrm{~cm}$, and the leaf surface was $12.2 \mathrm{~cm}^{2}$. In the second variant, the number of branches was 11 , the number of leaves was 193, the root length was $173 \mathrm{~cm}$, and the leaf surface was 12.8 $\mathrm{cm}^{2}$. In the third variant, the number of branches was 13 , the number of leaves was 232, the root length was $214 \mathrm{~cm}$, and the leaf surface was $14.0 \mathrm{~cm}^{2}$. In the fourth variant, these figures were 14 branches, 284 leaves, $228 \mathrm{~cm}$ of root length and $16.2 \mathrm{~cm}^{2}$ of leaf surface.

As a result, the number of branches relative to the control was 1.4 times increased. The number of leaves, root length and surface area of the leaf were improved by 1.3 times, 1.5 times and 1.4 times respectively (Table 2 ).

Table 2. The effect of mineral fertilizers on medicinal Salvia plant

\begin{tabular}{|l|c|c|c|c|}
\hline \multirow{2}{*}{ Variants } & \multicolumn{4}{|c|}{ For a single model of a plant } \\
\cline { 2 - 5 } & $\begin{array}{c}\text { number of leaves, } \\
\text { pcs }\end{array}$ & $\begin{array}{c}\text { number of } \\
\text { branches, pcs }\end{array}$ & root length, sm & Leaf surface, sm $^{2}$ \\
\hline Control & 184 & 10 & 154 & 12.2 \\
\hline $\mathrm{N}_{30} \mathrm{P}_{60} \mathrm{~K}_{40}$ & 193 & 11 & 173 & 12.8 \\
\hline $\mathrm{N}_{60} \mathrm{P}_{60} \mathrm{~K}_{40}$ & 232 & 13 & 214 & 14.0 \\
\hline $\mathrm{N}_{90} \mathrm{P}_{60} \mathrm{~K}_{40}$ & 284 & 14 & 228 & 16.2 \\
\hline
\end{tabular}

\subsection{Productivity indicators of cuttings of Salvia plant}

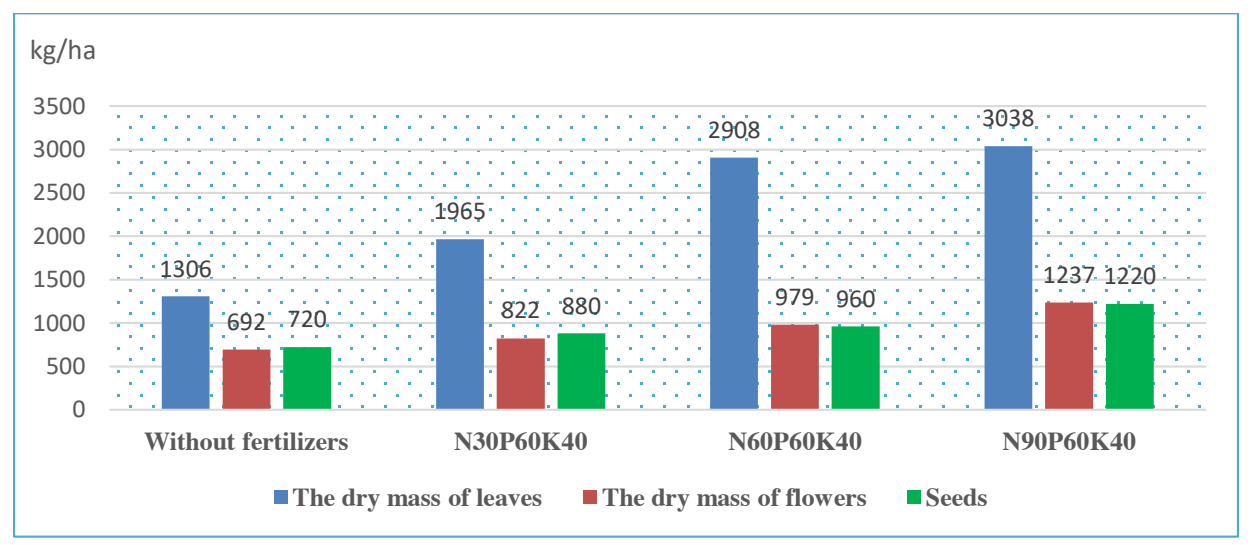

Fig. 2. Yield indicators of leaves, flowers, raw materials, and seeds of seedling development of salvia plant

After analyzing the wet weight of the raw material of the cuttings grown in the experiment, they were dried and remeasured and the yield was determined for an average of $1 \mathrm{~kg} / \mathrm{ha}$.

In the studies, the effects of applying mineral fertilizers with different norms for the Salvia plant seedlings were identified. 
Dry mass of flowers $69.2 \mathrm{~g}, 692 \mathrm{~kg} / \mathrm{ha}$ under control in $1 \mathrm{~m}^{2}$ area; In the option of mineral fertilizers applied by N90P60K40 norms, the productivity was $123.7 \mathrm{~g}$ per $1 \mathrm{~m} 2,1237 \mathrm{~g} / \mathrm{ha}$ per hectare. It was observed that the dry mass of flowers was 1.7 times higher than the control, which was 178 percent.

A cultivated Salvia seed under control was $72 \mathrm{~g}$ per $1 \mathrm{~m}^{2}$, which is $720 \mathrm{~kg}$ per hectare. In the second and third experiments the results were $88 \mathrm{~g}(880 \mathrm{~kg}$ per hectare) and $96 \mathrm{~g}(960 \mathrm{~kg} / \mathrm{ha})$ respectively. In the fourth option it was $122 \mathrm{~g} \mathrm{per} \mathrm{m}^{2}$, thus $1220 \mathrm{~kg} / \mathrm{ha}$. Seeds of the mature plant were found to increase 1.6 times or $169 \%$ compared to the control (Fig. 2.).

\section{Conclusions}

Based on the above data, it can be concluded that the application of different standards of mineral fertilizers for the accelerated cultivation of seedlings and cuttings of medicinal plants grown in the soil-climatic conditions of Syrdarya region increased the number of branches by 1.2-1.4 times, the number of leaves by 1.5-1.6 times, leaf surface area by 1.3 times, and the root development by 1.4 times.

When mineral fertilizers are applied to the seeds and cuttings of medicinal Salvia with nitrogen-90, phosphorus-60, potassium-40 norms, the dry mass of raw material (leaves) was 227 percent higher than the control, and the dry mass of flowers and seeds was $164 \%$ higher than the control.

It was found that the yields were higher in cuttings than in the seedlings of Salvia plant grown in the study areas.

\section{References}

1. S.L. Chen, H. Yao, J.P. Han, C. Liu, J.Y. Song, L.C. Shi, Y.J. Zhu, X.Y. Ma, T. Gao, X.H. Pang, K. Luo, Y. Li, X.W. Li, X.C. Jia, Y.L. Lin, C. Leon, Validation of the ITS2 region as a novel DNA barcode for identifying medicinal plant species, PLoS ONE. 5, e8613 (2010)

2. S.M. Chacko, P.T. Thambi, R. Kuttan, I. Nishigaki, Beneficial effects of green tea: a literature review, Chin Med. 5,13 (2010)

3. A.C. Hamilton, Medicinal plants, conservation and livelihoods, Biodivers Conserv., 13,1477-1517 (2004)

4. I.B. Cole, P.K. Saxena, S.J. Murch, Medicinal biotechnology in the genus scutellaria, In Vitro Cell Dev Plant., 43, 318-327 (2007)

5. M. Ekor, The growing use of herbal medicines: issues relating to adverse reactions and challenges in monitoring safety, Frontiers in pharmacology, 4, 177 (2014)

6. A. Sofowora, E. Ogunbodede, A. Onayade, The role and place of medicinal plants in the strategies for disease prevention, African journal of traditional, complementary, and alternative medicines : AJTCAM, 10(5), 210-229 (2013)

7. N. Toshpulatov, O. Tursunov, D. Kodirov, G. Kholmuratova, Environmentally friendly technology for the destruction of tobacco mosaic viruses (TMV) from selected species of plants, IOP Conf. Ser.: Earth Environ. Sci. 614, 012133 (2020)

8. J.W. Dobrowolski, O. Tursunov, O. Pirimov, O.J. Nazarova, Laser Biotechnology for Nutritional Health, Sustainable Environment and Development IOP Conf. Ser.: Earth Environ. Sci., 614, 012108 (2020)

9. H.A. Shouket, I. Ameen, O. Tursunov, K. Kholikova, O. Pirimov, N. Kurbonov, I. Ibragimov, B. Mukimov Study on industrial applications of papain: A succinct review IOP Conf. Ser.: Earth Environ. Sci., 614, 012171 (2020)

10. J.W. Dobrowolski, D. Bedla, T. Czech, F. Gambus, K. Gorecka, W. Kiszcak, T. Kuzniar, R. Mazur, A. Nowak, M. Sliwka, O. Tursunov, A. Wagner, J. Wieczorek, M. Swiatek, Integrated Innovative Biotechnology for Optimization of Environmental Bioprocesses and a Green Economy Optimization and Applicability of Bioprocesses eds H. Purohit, V. Kalia, A. Vaidya, A. Khardenavis (Singapore: Springer) chapter 3 pp 27-71 (2017)

11. N.K. Safarova, E.B. Nikitina, D.A. Abdullaev, K.S. Safarov, Development of technological methods for the dissemination of rare species of ornamental and medicinal plants. Conference on Scientific and practical achievements and current problems in the field of Botany, Samarkand, pp. 67-68 (2014)

12. N.K. Safarova, A.S. Imamkhodzhaeva, K.S. Safarov, Influence of pre-sowing treatment on seed germination of introduced decorative and medicinal plants, Uzbek Biological Journal, 2, 25-27 (2015)

13. Q.H. Hojimatov, K.Y. Yuldashev, U.Sh. Shogulomov, O.Q. Hojimatov, Medicinal herbs - ointment for pain (phytotherapy), Tashkent (1995)

14. M. Nabiev, The blessing of Chatkal, Ibn Sino, Tashkent (2004) 
15. B.Yo. Tukhtaev, T.X. Makhkamov, A.A. Tulaganov, A.I. Mamatkarimov, A.V. Mahmudov, M.O. Allayarov, "Instructions" on the organization of plantations of medicinal and food plants and the preparation of raw materials, Tashkent (2015)

16. I.E. Akopov, Hemostatic plants. (Hemostatic and other medicinal properties of them.), "Medicine" UzSSR, Tashkent (1977)

17. A. Ergashev, O. Akhmedov, A. Abzalov, M. Yulchieva, S. Azimboev, Practical training in the field of technology of cultivation of medicinal plants, Tashkent (2010)

18. B.A. Dospekhov, Field experiment technique, Alliance, Moscow, (2011)

19. I.N. Beideman, Methods for studying the phenology of plants and plant communities, Methodical instructions, Science, Novosibirsk (1974). 